\title{
Penggunaan Metode IPA dan WebQual untuk Mengukur Kualitas Sistem Informasi Akademik
}

\author{
Dafid $^{1)}$ \\ ${ }^{1)}$ Program Studi Sistem Informasi, STMIK Global Informatika MDP \\ Jl. Rajawali No.14 Palembang 30113 \\ Email : dafid@mdp.ac.id ${ }^{1)}$
}

\begin{abstract}
Academic Information System is an online and interactive learning information system owned by universities. Its function is very important to support the academic activities and to improve the quality of teaching and learning. Excelllent educational services which good quality and easy to use can be reached by improving the quality of the learning web. In an effort to optimize the contribution of information technology and ensure the web services that have been provided are appropriate, it is necessary to know the level of service provided to improve quality. This research was conducted using the IPA method (Importance-Performance Analysis) which is used to measure the level of user satisfaction with the services provided and using the WebQual method to measure the quality of the learning web used. Data collection is done by conducting a questionnaire on STMIK XYZ Palembang students by giving 2 questions. Measurements are made by comparing the value between performance and importance of the assessment variable. The results showed that the quality of the SIA Simponi STMIK XYZ had not met the expectations of the users, so it was necessary for the manager to improve the services provided for all dimensions, namely usability (U), information quality (I), interaction quality (A) especially for variables which is included in fourth quadrant.
\end{abstract}

Keyword : Academic Information System, WebQual, Importance-Performance Analysis

\begin{abstract}
Abstrak
Sistem Informasi Akademik merupakan sistem informasi pembelajaran online dan interaktif yang dimiliki oleh perguruan tinggi. Fungsinya sangat penting untuk mendukung kelancaran kegiatan akademik maupun peningkatan kualitas belajar mengajar. Layanan pendidikan yang berkualitas secara fungsionalitas maupun yang mudah dalam penggunaan dapat dilakukan melalui perbaikan dan peningkatan kualitas web pembelajaran. Dalam usaha mengoptimalkan kontribusi teknologi informasi dan memastikan layanan web yang telah diberikan telah sesuai maka perlu diketahui tingkat layanan yang diberikan guna peningkatan kualitas. Penelitian ini dilakukan dengan menggunakan metode IPA (Importance-Performance Analysis) yang digunakan untuk mengukur tingkat kepuasan pengguna atas layanan yang diberikan serta menggunakan metode WebQual untuk mengukur kualitas dari web pembelajaran yang digunakan. Pengumpulan data dilakukan dengan melakukan kuesioner terhadap mahasiswa STMIK XYZ Palembang dengan memberikan 2bentuk pertanyaan. Pengukuran dilakukan dengan membandingkan nilai antara performance dengan importance dari variabel penilaian. Hasil penelitian menunjukkan bahwa kualitas SIA Simponi STMIK XYZ belum memenuhi harapan dari pengguna sehingga perlu upaya dari pihak pengelola untuk memperbaiki layanan yang diberikan untuk semua dimensi yang ada yaitu usability(U), information quality(I), interaction quality(A) terutama untuk variabel-vararibel yang termasuk dalam kuadran empat
\end{abstract}

Kata kunci : Sistem Informasi Akademik, WebQual, Importance-Performance Analysis 


\section{Pendahuluan}

Sistem Informasi Akademik mempunyai peran yang sangat penting di suatu perguruan tinggi. Selain memberikan layanan akademik, keberadaannya dapat meningkatkan keunggulan bersaing terhadap perguruan tinggi lain. Layanan yang berkualitas sangat menentukan kelancaran kegiatan akademik yang dilakukan. Pada saaat ini STMIK XYZ telah mengimplementasikan Sistem Informasi Akademik (SIA) yang berbasis web dengan nama SIMPONI (Sistem Informasi Pembelajaran Online dan Interaktif). SIA ini digunakan oleh sebagian besar mahasiswa dan dosen. Fungsinya sangat penting bagi STMIK XYZ yang selama ini dikenal sebagai kampus digital dan inovasi yang mana seluruh aspek kegiatan akademik semua berbasis SI/TI. STMIK XYZ menyadari sepenuhnya dengan melihat begitu pentingnya SIA ini maka perlu dilakukan usaha untuk lebih meningkatkan kualitas layanan yang selama ini diberikan. Selama ini belum diketahui kualitas layanan sepenuhnya sehingga dengan dilakukannya penelitian ini dapat diketahui persepsi pengguna terhadap kinerja dan harapan pengguna terhadap SIA yang ada. Dengan demikian dapat ditentukan besarnya gap atau kesenjangan yang ada sehingga dapat ditentukan usaha untuk mempertahankan layanan yang telah berkualitas baik serta meningkatkan layanan yang masih kurang (perlu diperbaiki) sesuai yang diinginkan pengguna. Penelitian ini menggunakan metode ImportancePerformance Analysis (IPA) dan WebQual 4.0. Metode IPA digunakan untuk mengetahui penilaian dari pengguna terhadap kualitas web yang diinginkan (Importance) dan terhadap kualitas web yang dirasakan saat ini (Performance). Dimensi-dimensi pengukuran kualitas web menggunakan metode WebQual yang memiliki 22 kriteria kualitas web. Tingkat kualitas dapat ditunjukkan dengan menghitung gap antara nilai Performance dan Importance. Selanjutnya hasil pengukuran dapat menjadi umpan balik bagi manajemen STMIK XYZ untuk melakukan perbaikan-perbaikan dalam rangka meningkatkan kualitas layanan SIA. Penelitian sebelumnya melakukan penelitian tidak dengan menggunakan metode khusus pengukuran web melainkan dengan menggunakan metode analisa SEM yang menggunakan variabel system quality, information quality, intention to use dan system use. Penelitian tersebut menghasilkan kesimpulan bahwa kualitas informasi berpengaruh positif terhadap kualitas sistem, kualitas informasi berpengaruh positif terhadap minat pengguna, kualitas sistem berpengaruh secara positif terhadap minat pengguna, minat pengguna berpengaruh positif terhadap penggunaan sistem dan kualitas sistem berpengaruh positif terhadap penggunaan sistem. Sehingga penggunaan SIMPONI sangat mempengaruhi aktivitas kegiatan belajar mahasiswa dalam melihat pengumuman, melihat tingkat absensi dan mengakses informasi terutama materi yang disampaikan dosen pengampuh mata kuliah (Mulyati, Anggoro dan Dorie, 2017). Penelitian ini dilengkapi oleh penelitian yang dilakukan dengan menggunakan metode WebQual dengan lebih memfokuskan pada kepuasan pengguna akhir untuk mengukur kualitas SIMPONI (Dafid dan Dien, 2018). Penelitian ini menguji hubungan antara variabel usability $(U)$, information quality $(I)$, interaction quality $(A)$ dengan variabel user satisfaction $(S)$. Hasil dari penelitian ini menunjukan korelasi positif yang cukup berarti untuk variabel $U$ dan I terhadap S, sedangkan untuk variabel $\mathrm{A}$ dan $\mathrm{S}$ menunjukkan adanya korelasi positif yang tinggi atau kuat. Berbeda dengan penelitian yang dilakukan oleh dilakukan oleh (Budi Setiawan dan Muhammad Fauzi, 2015) dalam penelitian ini sudah menggabungkan 2 metode yaitu metode IPA dan WebQual. Hasil penelitiannya menunjukkan hasil kesenjangan atau gap secara keseluruhan untuk semua dimensi dimana nilai kesenjangan terbesar terdapat pada dimensi information sehingga dapat disimpulkan bahwa web secara aktual dirasakan belum memenuhi kualitas ideal terutama yang berhubungan dengan informasi dan layanan yang terdapat pada web.

\section{A. WebQual}

WebQual merupakan salah satu metode atau teknik pengukuran kualitas website berdasarkan persepsi pengguna akhir. Metode ini merupakan pengembangan dari SERVQUAL yang banyak digunakan sebelumnya pada pengukuran kualitas jasa. WebQual sudah mulai dikembangkan sejak tahun 1998 dan telah mengalami beberapa interaksi dalam penyusunan dimensi dan butir pertanyaannya. WebQual 4.0 disusun berdasarkan penelitian pada tiga area (dimensi) kualitas sebagaimana termuat dalam tabel 1 sampai tabel 3(Iman Sanjaya, 2012).

Tabel 1. Dimensi Kemudahan Penggunaan (usability)

\begin{tabular}{|c|l|}
\hline No & \multicolumn{1}{|c|}{ Deskripsi Indikator } \\
\hline 1 & $\begin{array}{l}\text { Pengguna merasa mudah untuk mempelajari } \\
\text { pengoperasian website (U1) }\end{array}$ \\
\hline 2 & $\begin{array}{l}\text { Interaksi antara website dengan pengguna jelas } \\
\text { dan mudah dipahami (U2) }\end{array}$ \\
\hline 3 & $\begin{array}{l}\text { Pengguna merasa mudah untuk bernavigasi } \\
\text { dalam website (U3) }\end{array}$ \\
\hline 4 & $\begin{array}{l}\text { Pengguna merasa website mudah untuk } \\
\text { digunakan (U4) }\end{array}$ \\
\hline 5 & Website memiliki tampilan yang menarik (U5) \\
\hline 6 & Desain sesuai dengan jenis website (U6) \\
\hline 7 & Website mengandung kompetensi (U7) \\
\hline 8 & $\begin{array}{l}\text { Website menciptakan pengalaman positif bagi } \\
\text { pengguna(U8) }\end{array}$ \\
\hline
\end{tabular}

Sumber: http://www.webqual.co.uk/instrument.htm

Tabel 2. Dimensi Kualitas informasi (Information Quality)

\begin{tabular}{|c|lcc|}
\hline No & \multicolumn{3}{|c|}{ Deskripsi Indikator } \\
\hline 1 & $\begin{array}{l}\text { Webste menyediakan informasi yang akurat } \\
\text { (I1) }\end{array}$ & $\begin{array}{l}\text { Website menyediakan informasi yang } \\
\text { terpercaya (I2) }\end{array}$ \\
\hline 2
\end{tabular}




\begin{tabular}{|c|l|}
\hline 3 & $\begin{array}{l}\text { Website menyediakan informasi yang tepat } \\
\text { waktu (I3) }\end{array}$ \\
\hline 4 & $\begin{array}{l}\text { Website menyediakan informasi yang relevan } \\
\text { (I4) }\end{array}$ \\
\hline 5 & $\begin{array}{l}\text { Website menyediakan informasi yang mudah } \\
\text { dimengerti (I5) }\end{array}$ \\
\hline 6 & $\begin{array}{l}\text { Website memberikan informasi yang detail } \\
\text { pada level yang tepat (I6) }\end{array}$ \\
\hline 7 & $\begin{array}{l}\text { Website menyajikan informasi dalam format } \\
\text { yang tepat (I7) }\end{array}$ \\
\hline
\end{tabular}

Sumber: http://www.webqual.co.uk/instrument.htm

Tabel 3. Dimensi Kualitas Interaksi (interaction quality)

\begin{tabular}{|c|c|}
\hline No & Deskripsi Indikator \\
\hline 1 & Website memiliki reputasi yang baik (A1) \\
\hline 2 & $\begin{array}{l}\text { Pengguna merasa aman untuk melakukan } \\
\text { transaksi (A2) }\end{array}$ \\
\hline 3 & $\begin{array}{l}\text { Pengguna merasa aman terhadap informasi } \\
\text { pribadinya (A3) }\end{array}$ \\
\hline 4 & $\begin{array}{l}\text { Website memberi ruang untuk personalisasi } \\
\text { (A4) }\end{array}$ \\
\hline 5 & $\begin{array}{l}\text { Website memberikan ruang untuk komunitas } \\
\text { (A5) }\end{array}$ \\
\hline 6 & $\begin{array}{l}\text { Website memberikan kemudahan untuk } \\
\text { berkomunikasi dengan organisasi (A6) }\end{array}$ \\
\hline 7 & $\begin{array}{l}\text { Pengguna merasa yakin bahwa barang/jasa } \\
\text { akan dikirim sebagaimana yang telah } \\
\text { dijanjikan (A7) }\end{array}$ \\
\hline
\end{tabular}

Sumber: http://www.webqual.co.uk/instrument.htm

\section{B. Importance Performance Analysis (IPA)}

Importance-Performance Analysis adalah teknik yang sederhana dan digunakan untuk mengidentifikasi atribut-atribut dari produk atau pelayanan yang paling dibutuhkan dari adanya sebuah pengembangan atau kandidat untuk kondisi penghematan biaya yang dimungkinkan tanpa kerugian yang signifikan terhadap kualitas secara keseluruhan. IPA diperkenalkan oleh Martilla dan James dan terdokumentasi dengan baik serta telah mampu menunjukkan kemampuan untuk menyediakan manajerial pelayanan dengan informasi yang berharga untuk pengukuran kepuasan keduanya dan alokasi sumber daya yang efisien di dalam format yang sesuai dengan mudah (Magal dan Levenburg, 2005). Metode Importance Performance Analysis (IPA) pertama kali diperkenalkan oleh Martilla dan James (1977) dengan tujuan untuk mengukur hubungan antara persepsi konsumen dan prioritas peningkatan kualitas produk/jasa yang dikenal pula sebagai quadrant analysis (Latu dan Everett, 2000). IPA telah diterima secara umum dan dipergunakan pada berbagai bidang kajian karena kemudahan untuk diterapkan dan tampilan hasil analisa yang memudahkan usulan perbaikan kinerja (Martinez, 2003). IPA mempunyai fungsi utama untuk menampilkan informasi berkaitan dengan faktor-faktor pelayanan yang menurut konsumen sangat mempengaruhi kepuasan dan loyalitas mereka, dan faktor-faktor pelayanan yang menurut konsumen perlu ditingkatkan karena kondisi saat ini belum memuaskan. IPA menggabungkan pengukuran faktor tingkat kepentingan dan tingkat kepuasan dalam grafik dua dimensi yang memudahkan penjelasan data dan mendapatkan usulan praktis. Interpretasi grafik IPA sangat mudah, dimana grafik IPA dibagi menjadi empat buah kuadran berdasarkan hasil pengukuran importanceperformance. Mengenai metode IPA bahwa atribut performance digambarkan sepanjang sumbu $\mathrm{X}$ dan atribut importance (kepuasan dan kualitas pelayanan) digambarkan sepanjang sumbu Y(Martila dan James, 1977). Berikut penjelasan untuk masing-masing kuadran (Martilla dan James, 1977):

1. Kuadran pertama:Pertahankan Kinerja (high importance dan high perfomance). Dianggap sebagai faktor penunjang bagi kepuasan konsumen sehingga manajemen wajib memastikan kinerja institusinya dapat mempertahankan prestasi yang telah dicapai.

2. Kuadran kedua:Cenderung Berlebihan (low importance dan high performance). Dianggap tidak terlalu penting sehingga manajemen bisa mengalokasikan sumber daya yang terkait dengan faktor-faktor tersebut kepada faktor-faktor lain yang lebih membutuhkan peningkatan penanganan.

3. Kuadran ketiga:Prioritas rendah (low importance dan low performance). Dianggap mempunyai tingkat kepuasan yang rendah sekaligus dianggap tidak terlalu penting oleh konsumen, sehingga manajemen tidak perlu memprioritaskan faktor tersebut.

4. Kudran keempat:Tingkatkan Kinerja (high importance dan low performance). Dianggap faktor yang sangat penting namun belum memuaskan untuk kondisi saat ini sehingga harus menjadi perhatian bagi manajemen untuk mengalokasikan sumber daya yang memadai. Berikut ini adalah penggambaran dari pembagian kuadran yang terdapat pada IPA yang dapat dilihat pada gambar 1 dibawah ini.

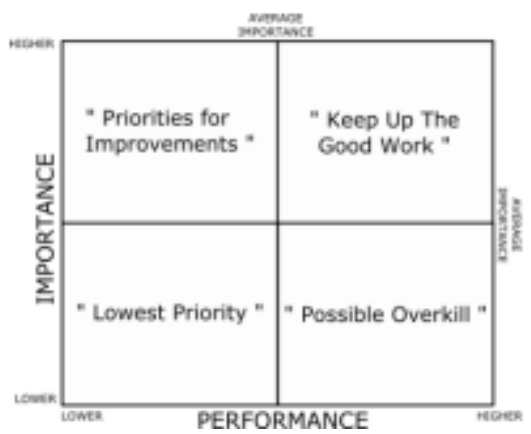

Gambar 1. Kuadran IPA (Brandt, 2000)

\section{Metodologi Penelitian}

Pada gambar 3 merupakan metode penelitian yang menggambarkan tahapan penelitian yang dilakukan beserta metode yang digunakan dengan penjelasan gambar sebagai berikut:

a. Observasi

Pada penelitian ini dimulai dengan melakukan pengamatan pada STMIK XYZ Palembang 
khususnya pada kegiatan akademik untuk mencari bahasan pada penelitian ini.

b. Perumusan Masalah

Pada tahapan ini melihat permasalahan yang akan diangkat dalam penelitian dan mencoba untuk menjawab permasalahan yang ada.

c. Studi literature

Tahapan selanjutnya adalah mencari studi literatur mengenai tinjauan pustaka yang berkaitan dengan penelitian yang akan dilaksanakan serta literatur penelitian sebelumnya yang terkait dengan tema penelitian.

d. Metode yang Digunakan

Metode yang digunakan adalah Metode WebQual 4.0 dan IPA (Importance-Performance Analysis). Metode WebQual 4.0 merupakan metode atau teknik pengukuran kualitas website berdasarkan persepsi pengguna akhir yang memiliki tiga dimensi kualitas yaitu Dimensi Kemudahan Penggunaan (usability), Dimensi Kualitas informasi (information quality) dan Dimensi Kualitas Interaksi (interaction quality) sedangkan metode IPA merupakan metode untuk mengidentifikasi atribut-atribut dari produk atau pelayanan yang paling dibutuhkan dari adanya sebuah pengembangan atau kandidat untuk kondisi penghematan biaya yang dimungkinkan tanpa kerugian yang signifikan terhadap kualitas secara keseluruhan.

e. Metode Pengumpulan Data

Metode pengumpulan data yang digunakan yaitu dengan melakukan kuesioner. Kuesioner dilakukan kepada mahasiswa STMIK XYZ sebagai sampel dari beberapa program studi. Skala pengukuran yang digunakan adalah skala Likert dengan skala mulai dari 1 (sangat tidak setuju) 2 (tidak setuju) 3 (netaral) 4 (setuju) hingga 5 (sangat setuju).

f. Analisis

Analisis dilakukan dengan melakukan uji validitas dan realibilitas untuk menguji apakah butir-butir pertanyaan yang diajukan dalam kuesioner sudah valid dan reliabel atau tidak? Apabila tidak valid maka pertanyaan tersebut akan dibuang dari model penelitian. Selanjutnya dilakukan analisis gap untuk melihat tingkat kualitas dari SIA yang ditinjau dari nilai kesenjangan (gap) antara kualitas yang dirasakan (aktual) dan kualitas yang diinginkan atau diharapkan (ideal) berdasarkan dimensi dari WebQual yang dapat dilihat pada gambar 2.

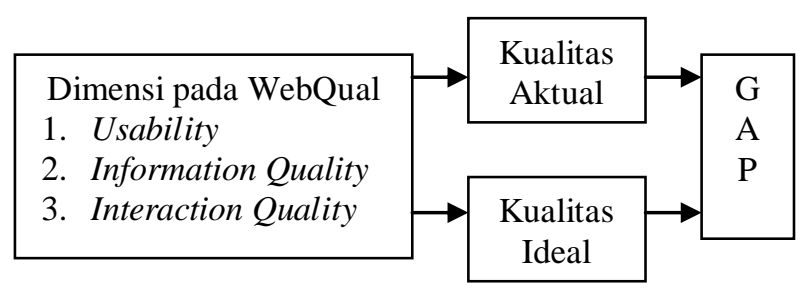

Gambar 2. Variabel penelitian g. Kesimpulan

Pada tahap ini dilakukan penarikan kesimpulan berdasarkan hasil dari analisa dan pengujian data yang dilakukan berdasarkan dimensi WebQual.

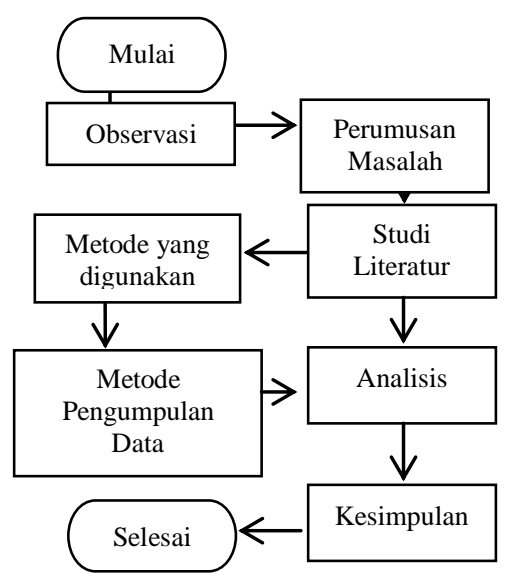

Gambar 3. Metode Penelitian

\section{Pembahasan}

\section{A. Layanan SI/TI pada Sistem Informasi Akademik}

SIA Simponi menyediakan layanan SI/TI kepada penggunanya untuk pengelolaan kegiatan akademik. Bagi mahasiswa layanan yang diberikan meliputi pengelolaan KRS (Kartu Rencana Studi), jadwal, pengumpulan tugas, download materi, monitoring nilai, bimbingan dan sidang skripsi serta permohonan untuk permintaan surat.

\section{B. Uji Validitas dan Reliabilitas}

Uji validitas dalam penelitian ini menggunakan metode analisis faktor, sedangkan uji reliabilitas menggunakan Cronbach Alpha dengan alat bantu software statistik SPSS. Hasil perhitungan menunjukkan Corrected Item-Total Correlation dari masing-masing 22 butir pertanyaan berkisar antara 0,321 - 0,773. Sedangkan $r$ table (tabel koefisien relasi dengan metode product momen) dengan signifikansi $5 \%$ dan jumlah sampling $(\mathrm{n}=100)$ diperoleh $\mathrm{r}$ tabel dengan nilai 0,202. Syarat indikator suatu variabel yang dinyatakan dengan setiap item pernyataan kuesioner tersebut valid adalah jika nilai setiap item pertanyaan kuesioner mempunyai nilai Corrected Item-Total Correlation lebih besar dari $r$ table. Jika dibandingkan dengan nilai $\mathrm{r}$ table maka semua indikator valid $(<0,202)$. Jika nilai apha $<0,6$ maka reliabilitas buruk, jika sekitar 0,7 maka reliabilitas masih dapat diterima dan jika > 0.8 maka reliabilitas sangat baik. Berdasarkan hasil uji reliabilitas menggunakan Cronbach Alpha diperoleh nilai Cronbach's Alpha 0,904 berarti diperoleh nilai alpha $>0,9$ dengan demikian reliabilitas sangat baik.

\section{Analisis WebQual dan IPA}

Untuk menganalisa gap antara kualitas aktual dan kualitas ideal dari pengguna SIA Simponi di STMIK $\mathrm{XYZ}$, digunakan Paired Sample t-Test. Perhitungan 
dilakukan dengan menggunakan alat bantu software statistik SPSS. Nilai significant yang digunakan dalam pengujian ini adalah 0,05. Adapun rumus Paired Sample $t$-Test adalah sebagai berikut:

$$
t=\frac{\bar{D}}{\left(\frac{S D}{\sqrt{N}}\right)}
$$

Keterangan:

$t$ : nilai $\mathrm{t}$

$\bar{D}$ : rata-rata beda antara 2 pengukuran

SD : standar deviasi

$\mathrm{N}$ : banyak sample

Masing-masing responden diberikan 2 jenis pertanyaan berdasarkan persepsinya, yang pertama adalah yang berkaitan dengan kualitas aktual SIA Simponi yang disediakan STMIK XYZ saat ini lalu yang kedua adalah yang berkaitan dengan kualitas ideal yang merupakan kualitas yang diharapakan pengguna terhadap Simponi STMIK XYZ. Selanjutnya kualitas SIA dapat ditentukan dengan membandingkan jawaban dari kedua jenis pertanyaan tersebut untuk dilakukan analisa gap. Analisis gap dilakukan untuk melihat kualitas SIA dari nilai gap yang ada. Proses untuk menentukan nilai gap dilakukan dengan cara menghitung selisih nilai antara nilai kualitas aktual (Performance) dengan nilai kualitas ideal (Importance) menggunakan rumus sebagai berikut:

Qi $($ Gap $)=$ Performance $(i)-$ Importance $(i)$

Keterangan:

Qi (Gap) : : tingkat kesenjangan kualitas

Performance(i) : nilai kualitas aktual atau saat ini Importance(i) : nilai kualitas ideal atau harapan

Tingkat kualitas yang baik ditandakan dengan nilai positif atau Qi (Gap) $\geq 0$ yang berarti bahwa kualitas aktual telah memenuhi kualitas ideal yang diharapkan oleh para pengguna. Sebaliknya jika tingkat kualitas yang dihasilkan Qi (Gap) < 0 atau bernilai negatif maka tingkat kualitas dinyatakan kurang dan belum dapat memenuhi keinginan ideal dari pengguna. Berikut ini adalah tabel yang menunjukkan nilai performance dan importance beserta nilai gap dari masing-masing dimensi yaitu usability, information quality dan interaction quality.

Tabel 4. Nilai Gap

\begin{tabular}{|c|c|c|c|c|}
\hline Dimensi & Variabel & Perf & Imp & $\mathbf{Q}$ \\
\hline \multirow{7}{*}{ 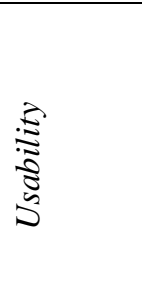 } & U1 & 3,76 & 4,73 & $-0,97$ \\
\hline & $\mathrm{U} 2$ & 3,55 & 4,42 & $-0,87$ \\
\hline & U3 & 3,43 & 4,64 & $-1,21$ \\
\hline & $\mathrm{U} 4$ & 3,52 & 4,67 & $-1,15$ \\
\hline & U5 & 3,62 & 4,71 & $-1,09$ \\
\hline & U6 & 3,74 & 4,74 & $-1,00$ \\
\hline & U7 & 3,58 & 4,54 & $-0,96$ \\
\hline
\end{tabular}

\begin{tabular}{|c|c|c|c|c|}
\hline & U8 & 3,75 & 4,26 & $-0,51$ \\
\hline \multicolumn{2}{|c|}{ Rata-rata Usability } & 3,76 & 4,50 & $-0,74$ \\
\hline \multirow{7}{*}{ 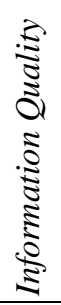 } & I1 & 3,84 & 4,61 & $-0,77$ \\
\hline & $\mathrm{I} 2$ & 3,77 & 4,69 & $-0,92$ \\
\hline & I3 & 3,28 & 4,53 & $-1,25$ \\
\hline & $\mathrm{I} 4$ & 3,66 & 4,63 & $-0,97$ \\
\hline & I5 & 3,27 & 4,58 & $-1,31$ \\
\hline & I6 & 3,54 & 4,76 & $-1,22$ \\
\hline & $\mathrm{I} 7$ & 3,37 & 4,65 & $-1,28$ \\
\hline \multicolumn{2}{|c|}{$\begin{array}{c}\text { Rata-rata } \\
\text { Information Quality }\end{array}$} & 3.61 & 4.63 & $-1,03$ \\
\hline \multirow{7}{*}{ 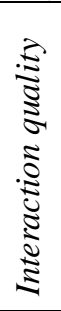 } & A1 & 3,37 & 4,61 & $-1,24$ \\
\hline & $\mathrm{A} 2$ & 3,44 & 4,51 & $-1,07$ \\
\hline & A3 & 3,21 & 4,80 & $-1,59$ \\
\hline & A4 & 3,87 & 4,23 & $-0,36$ \\
\hline & A5 & 3,76 & 4,68 & $-0,92$ \\
\hline & A6 & 3,42 & 4,74 & $-1,32$ \\
\hline & A7 & 3,57 & 4,43 & $-0,86$ \\
\hline \multicolumn{2}{|c|}{$\begin{array}{c}\text { Rata-rata } \\
\text { Interaction quality }\end{array}$} & 3,47 & 4,57 & $-1,05$ \\
\hline \multicolumn{2}{|c|}{ Rata-rata keseluruhan } & 3,61 & 4,5 & $-0,94$ \\
\hline
\end{tabular}

Berdasarkan tabel 4 diatas dapat dilihat nilai gap (selisih antara performance dan importance untuk semua variabel untuk semua dimensi (usability, information quality, interaction quality). Berikut ini analisis gap yang teridentifikasi untuk masing-masing dimensi:

1. Dimensi usability

Berdasarkan hasil perhitungan pada tabel 4 diketahui bahwa sebagian besar pengguna menjawab "sangat setuju" untuk importance dengan nilai rata-rata 4,26. Sedangkan untuk performance nilai rata-rata sebesar 3,75 yang berarti sebagian besar pengguna merasa"puas" dengan layanan yang diberikan. Nilai gap menunjukkan angka sebesar -0,51 yang berarti bahwa kinerja dari SIA Simponi belum memenuhi keinginan pengguna. Variabel yang memiliki gap terbesar adalah U3 yaitu "Pengguna merasa mudah untuk bernavigasi dalam website" dengan selisih sebesar -1,21. Dari hasil perhitungan Paired Sample $t$-Test diperoleh nilai 0,001 untuk nilai significant yang berarti bahwa masih ada gap antara kinerja dengan harapan pengguna.

\section{Dimensi information quality}

Berdasarkan hasil perhitungan pada tabel 4 diketahui bahwa sebagian besar pengguna menjawab "sangat setuju" untuk importance dengan nilai rata-rata 4,63. Sedangkan untuk performance nilai rata-rata sebesar 3,61 yang berarti sebagian besar pengguna merasa"puas" dengan layanan yang diberikan. Nilai gap menunjukkan angka sebesar -1,03 yang berarti bahwa kinerja dari SIA Simponi belum memenuhi keinginan pengguna. Variabel yang memiliki gap terbesar adalah I5 yaitu "Website menyediakan informasi yang mudah dimengerti" dengan selisih sebesar -1,31. Dari hasil perhitungan Paired Sample $t$-Test diperoleh nilai 0,002 untuk nilai significant yang berarti bahwa masih ada gap antara kinerja dengan harapan pengguna. 


\section{Dimensi Interaction Quality}

Berdasarkan hasil perhitungan pada tabel 4 diketahui bahwa sebagian besar pengguna menjawab "sangat setuju" untuk importance dengan nilai rata-rata 4,57. Sedangkan untuk performance nilai rata-rata sebesar 3,47 yang berarti sebagian besar pengguna merasa"puas" dengan layanan yang diberikan. Nilai gap menunjukkan angka sebesar -1,05 yang berarti bahwa kinerja dari SIA Simponi belum memenuhi keinginan pengguna. Variabel yang memiliki gap terbesar adalah A3 yaitu "Pengguna merasa aman terhadap informasi pribadinya" dengan selisih sebesar -1,59. Dari hasil perhitungan Paired Sample t-Test diperoleh nilai 0,009 untuk nilai significant yang berarti bahwa masih ada gap antara kinerja dengan harapan pengguna.

Dari tabel 4 diatas untuk semua variabel nilai gap semuanya negatif yang berarti semua variabel belum memenuhi harapan pengguna. Nilai gap rata-rata keseluruhan -0,94. Dengan demikian dapat dinyatakan kualitas SIA Simponi masih buruk. Dimensi yang memiliki gap terbesar adalah Interaction Quality dengan nilai sebesar -1,05. Importance-Performance Analysis digunakan untuk melihat variabel kualitas SIA yang mana saja yang telah sesuai dengan harapan pengguna dan yang mana saja masih membutuhkan perbaikan. Hasil dari analisis IPA menunjukkan letak masingmasing variabel dalam kuadaran IPA. Setiap kuadaran memiliki interpretasi spesifik yang menjelaskan tindakan strategis apa yang sebaiknya dilakukan untuk masingmasing variabel. Berikut ini pengelompokkan masingmasing variabel berdasarkan data pada tabel 4 diatas:

\section{Kuadran 1 (high importance dan high perfomance)}

Variabel-variabel yang masuk kuadran ini adalah U1, U5, U6, I1, I2, I4 dan A5. Variabel yang masuk kuadran 1 ini berarti sudah sesuai dengan harapan pengguna dan harus dipertahankan menjadi lebih baik

\section{Kuadran 2 (low importance dan high performance)} Variabel-variabel yang masuk kuadran ini adalah U8 dan A4. Variabel yang masuk kuadran 1 ini berarti sudah melampaui harapan pengguna dan dapat diabaikan untuk prioritas pengembangan.

\section{Kuadran 3 (low importance dan low performance)}

Variabel-variabel yang masuk kuadran ini adalah U2 dan A7. Variabel yang masuk kuadran 1 ini berarti tidak sesuai harapan pengguna dan inipun dapat diabaikan untuk prioritas pengembangan.

\section{Kuadran 4 (high importance dan low performance)} Variabel-variabel yang masuk kuadran ini adalah U3, U4,U7, I3, I5, I6, I7, A1, A2, A3 dan A6. Variabel yang masuk kuadran 1 ini berarti tidak sesuai harapan pengguna dan mempunyai tingkat kepentingan yang tingi. Dengan demikian variabel yang masuk kuadran ini harus diprioritaskan untuk dikembangkan/perbaikan.

\section{Kesimpulan}

Dari hasil pembahasan sebelumnya berdasarkan datadata statistik yang ada dapat simpulkan bahwa kualitas SIA Simponi STMIK XYZ belum memenuhi harapan dari pengguna. Untuk meningkatkan kualitas SIA Simponi, STMIK XYZ perlu melakukan perbaikan di semua dimensi baik usability, information quality maupun interaction quality melalui memberikan web dengan input dan ouput yang mudah,peningkatan waktu response time, penyediaan informasi yang lebih akurat dan up to date, memberikan jaminan keamananan data, mengurangi gangguan-gangguan pada saat menggunakan SIA.

\section{Daftar Pustaka}

Brandt, D.R., 2000. An "outside-in" approach to determining customer-driven priorities for improvement and innovation. White Paper Series, 2(2), pp.1-8.

Dafid, and Novita, D., 2018. Metode WebQual 4.0 Untuk Analisis Kualitas Web Pembelajaran. Jurnal Teknologi Komputer dan Sistem Informasi, 1(2), pp.17-21.

Hasan, M. Iqbal, Pokok-Pokok Materi Statistik 2 (Statistik Inferensi), Bumi Aksara, (2005), pp:30.

Latu, T.M. and Everett, A.M., 2000. Review of satisfaction research and measurement approaches. Wellington, NZ: Department of Conservation.

Magal, S.R. and Levenburg, N.M., 2005, January. Using importance-performance analysis to evaluate ebusiness strategies among small businesses. In null (p. 176a). IEEE.

Martilla, J.A. and James, J.C., 1977. Importanceperformance analysis. The journal of marketing, pp.77-79.

Martinez, C.L., 2003. Evaluation report: tools cluster networking meeting\# 1 , CenterPoint Institute. Inc, Arizona.

Mulyati, M., 2017. Pengaruh Kualitas Sistem Dan Informasi Pada Sistem Informasi Pembelajaran Online Terhadap Minat Pengguna Dan Penggunaan Sistem (Studi Kasus: Simponi AMIK MDP, STMIK GI MDP DAN STIE MDP). Jurnal TAM (Technology Acceptance Model), 8(2), pp.90-100.

Sanjaya, I., 2012. Pengukuran Kualitas layanan website kementerian kominfo dengan menggunakan metode webqual 4.0. Jurnal penelitian iptek-kom, 14(1), pp.1-14.

Santoso, B.S., Anwar, M.F. and Hermawati, S., 2016. Analisis Kualitas Website Menggunakan Metode Webqual Dan Importance-Performance Analysis (IPA) Pada Situs Kaskus. In National Conference on Information Technology and Technical Engineering (CITEE). Yogyakarta: citee. 